\title{
PELAKSANAAN FUNGSI PENGAWASAN SEBAGAIUPAYA MENCEGAH PERATURAN DAERAH BERMASALAH DI KABUPATEN BOJONEGORO
}

\author{
Bukhari Yasin ${ }^{1}$,Andrianto Prabowo ${ }^{2}$ \\ ${ }^{1}$ Fakultas Hukum Universitas Bojonegoro \\ Email : masteroflaw16@gmail.com ${ }^{1}$, andri.bjn@gmail.com²
}

\begin{abstract}
ABSTRAK
Penelitian ini bertujuan untuk mengetahui peran dan fungsi pengawasan Gubernur terhadap Peraturan Daerah.Metode penelitian terdiri dari jenis penelitian, metode pendekatan, sumber bahan hukum, teknik pengumpulan bahan hukum dan analisis bahan hukum.Dari hasil analisis maka dapat disimpulkan bahwa peran dan fungsi pengawasan Gubernur terhadap Peraturan Daerah adalah untuk memastikan bahwa Peraturan Daerah yang dibuat tersebut tidak bertentangan dengan peraturan perundang-undangan yang ada di atasnya agar tidak terjadi tumpang tindih baik dari segi kewenangan maupun dari segi materi muatan, dan Gubernur sebagai wakil dari pada Pemerintah Pusat yang ada di daerah diberi kewenangan untuk itu.
\end{abstract}

Kata Kunci: Pelaksanaan, Fungsi, Pengawasan,Peraturan Daerah.

\begin{abstract}
This study aims to determine the role and function of governor's supervision of regional regulations. The research method consists of the type of research, the approach method, the source of legal materials, the techniques of collecting legal materials and the analysis of legal materials. From the results of the analysis, it can be concluded that the role and function of the Governor's oversight of Regional Regulations is to ensure that the Regional Regulations made do not conflict with existing laws and regulations so that there is no overlap, both in terms of authority and in terms of content, and the Governor as the representative of the Central Government in the regions is given the authority to do this.
\end{abstract}

Keywords: Implementation, Functions, Supervision, Regional Regulations. 


\section{PENDAHULUAN}

Dalam strukturketatanegaraan Republik Indonesia sendiri terdapat pemisahan kekuasaan (separation of power) antara kekuasaan eksekutif, kekuasaan legisltif, dan kekuasaan yudikatif. 1 Peraturan Daerahmerupakan suatu produk hukum yang dikeluarkan oleh pemerintahan yang ada di daerah, baik sebagai pelaksanaan lebih lanjut atas perintah peraturan perundangundangan yang lebih tinggi tingkatannya maupun pengaturan dalam rangka menjalankan otonomi daerah sesuai dengan potensinya.Namun dalam pelaksanaan otonomi daerah ini tentu lah harus dalam konteks atau bingkai Negara Kesatuan Republik Indonesia (NKRI).

Pembentukan Peraturan Daerah, khususnya Peraturan Daerah Kabupaten/Kota adalah dalam rangka menjalankan fungsi pemerintahan yang ada di daerah Kabupaten/Kota,sehinggakewenanga $\mathrm{n}$ pembentukannya pun harus didasarkan atas persetujuan bersama antara Dewan Perwakilan Rakyat DaerahKabupaten/Kota dengan Buapati/Wali Kota sebagai Kepala Daerah. Peraturan Daerah yang dihasilkan tersebut diharapkan dapat menjadi dasar keputusan

dan/atau tindakan yang diambil oleh pemerintah yang ada di daerah sekaligus menjamin terselengaranya urusan pemerintahan yang adil dan makmur sesuai dengan amanat Undang-Undang Dasar Negara Republik Indonesia Tahun 1945.

${ }^{1}$ Jimly Asshiddiqie, Hukum Tata Negara dan Pilar-Pilar Demokrasi, (Jakarta: Sinar Grafika), 2011, hlm. 83.
Adapun kedudukan hukum Peraturan Daerah Kabupaten/Kota merupakan jenis peraturan perundang-undangan yang tingkatannya berada di bawah Peraturan Daerah Provinsi, dan oleh karenanya tidak boleh bertentangan atau menyimpang dari materi muatan Undang-Undang Dasar Negara Republik Indonesia Tahun 1945, Ketetapan Majelis Permusyawaratan Rakyat, Undang-Undang/Peraturan Pemerintah Pengganti UndangUndang, Peraturan Pemerintah, Peraturan Presiden maupun Peraturan Daerah Provinsi.Hal tersebut di atas dapat dilihat dalam ketentuan Pasal 7 Undang-Undang Republik Indonesia Nomor 12 Tahun 2011 Tentang Pembentukan Peraturan Perundang-undangan, yang mana jenis dan hierarki peraturan perundang-undangan di Indonesia berdasarkan tata urutannya dimulai dari Undang-Undang Dasar Negara Republik Indonesia Tahun 1945; Ketetapan Majelis Permusyawaratan Rakyat; Undang/PeraturanPemerintah Pengganti Undang-Undang; Peraturan Pemerintah; Peraturan Presiden; Peraturan Daerah Provinsi; dan Peraturan Daerah Kabupaten/Kota. Bahwa atas dasar hal tersebut di atas, merupakan suatu keniscayaan bagi DPRD Kabupaten/Kota bersama dengan Bupati/Wali Kota untuk benar-benar memperhatikan kesesuaian antara jenis dan materi muatan yang diatur dalam Peraturan Daerah, khususnya di Kabupaten Bojonegoro.

DidalampenyelenggaraanPemeri ntahanDaerah selain dikenal pengawasan preventif dan represif juga dikenal pengawasan umum. Yang dimaksud pengawasan umum adalah pengawasan yang dilakukan 
secara langsung oleh pemerintah pusat melalui kementerian ataupun yang dlakukan melalui pemerintah daerah tingkat Provinsi terhadap penyelenggaraan pemerintahan tingkat Kabupaten/Kota yang kewenangan tersebut didelegasikan melalui Undang-Undang Nomor 23 Tahun 2014 tentang Pemerintahan Daerah, dalam rangka ikut mengawasi segala bentuk penyelenggaraan pemerintahan daerah termasuk dalam hal produk hukum daerah baik itu yang berupa Peraturan Daerah, Peraturan Kepala Daerah maupun Keputusan Kepala Daerah. Pengawasan umum terkait dengan jalannya pemerintahan daerah sebelumnya telah termuat dalam Undang-Undang Nomor 5 Tahun 1976 yang diatur dalam Pasal 71, kemudian ditegaskan kembali dalam Undang-Undang Nomor 23 Tahun 2014 tentang Pemerintahan Daerah, sebagaimana telah diubah dengan Undang-Undang Nomor 9 Tahun 2015 Perubahan Kedua Atas Undang-Undaang Nomor 23 Tahun 2014 tentang Pemerintahan Daerah dan Peraturan Pemerintah Nomor 12 Tahun 2017 Tentang Pembinaan dan Pengawasan Penyelenggaraan Pemerintahan Daerah.

Secara historis, landasan hukum diterapkanya pengawasan umum ini adalah amanat dari Keputusan Presiden Republik Indonesia No. 44 Tahun 1974 dimana dalam keputusan tersebut memuat tentang kewajiban setiap departemen untuk untuk menyelenggarakan fungsi pengawasan atas pelaksanaan tugas pokoknya sesuai dengan kebijaksanaan umum yang ditetapkan oleh Presiden dan berlandaskan peraturan perundangundangan yang berlaku. Pengawasan umum yang dimksud dalam konteks ini yaitu pengawasan yang dilakukan oleh pemerintah pusat terhadap pemerintah daerah yang dimana program programnya telah direncanakan oleh pemerintah pusat melalui rencana strategis nasional. Pengawasan umum dimaksud agar pemerintah pusat dapat memperoleh target secara nasional melalui Rencana Pembangunan Jangka Panjang (RPJP).

Gubernur sebagai Wakil Pemerintaah Pusat yang berada di Daerah memiliki kewenangan yang begitu luas dalam hal melakukn Pembinaan dan Pengawasan terhadap Penyelenggaraan Pemerintahan Daerah Kabupaten/Kota, selain dari itu tugas dan kewenangan tersebut dapat didelegasikan kepada Wakil Gubernur.Artinya bahwa untuk menjalankan fungsi pengawasan terhadap penyelenggaraan pemerintah daerah kabupaten/kota gubernur tidak terikat untuk melaksanakan sendiri namun oleh undang undang diberikan kelonggaran sehingga fungsi tersebut dapat dijlankan oleh wakil gubernur.Berdasarkan ketentuan Pasal 91 Ayat (8) diatas bahwa pelaksanaan fungsi tersebut diatur melalui peraturan pemerintah.Adapun peraturan pemerintah sebagai aturan pelaksana fungsi tersebut adalah Peraturan Pemerintah Nomor 12 Tahun 2017 tentang Pembinaan dan Pengawasan Penyelenggaraan Pemerintahan Daerah.

Bahwa berdasarkan uraian tersebut di atas mendorong peneliti untuk mengangkat tema penelitianini tentang "Pelaksanaan Fungsi Pengawasan Sebagai Upaya Mencegah Peraturan Daerah Bermasalah di Kabupaten Bojonegoro".

\section{PERMASALAHAN}


Berdasarkan uraian tersebut di atas, maka permasalahan yang diajukan dalam penelitian ini adalah terkait peran dan fungsi pengawasan Gubernur terhadap Peraturan Daerah.

\section{METODE}

\section{Jenis Penelitian}

Dalam penelitian ini menggunakan jenis penelitian hukum normatif yaitu dengan bertumpu pada suatu peraturan peraturan perundangundang maupun konsep-konsep hukum yang dikemukakan oleh para ahli.

\section{Metode Pendekatan}

Di dalam penelitian ini menggunakan metode pendekatan peraturan perundang-undangan (statute approach) dan pendekatan konsep (conseptual approach). ${ }^{2}$

a. Pendekatan perundang-undangan (statuteapproach) adalah pendekatan yang dilakukan dengan menelaah semua undangundang dan regulasi yang bersangkut paut dengan isu hukum yang sedang ditangani. Pendekatan perundang-undangan dalam penelitian hukum normatif memiliki kegunaan baik secara praktis maupun akademis. $^{3}$

b. Pendekatan konsep (conseptualapproach) adalah pendekatan yang beranjak dari pandangan-pandangan dan doktrin-doktrin yang berkembang di dalam ilmu hukum, guna menemukan ide-ide yang melahirkan pengertian, konsep, dan asas hukum yang

2 Peter Mahmud Marzuki, Penelitian Hukum, Cet. 5, Edisi Pertama, PT Interpratama Offset, Jakarta, 2009, hal. 93. ${ }^{3}$ Ibid., hal. 96. relevan, sebagai sandaran dalam membangun suatu argumentasi hukum dalam memecahkan isu hukum yangdihadapi. ${ }^{4}$

\section{Sumber dan Jenis Bahan Hukum}

Bahan hukum merupakan sarana dari suatu penelitian yang dipergunakan untuk memecahkan masalah yang ada. Bahan hukum tersebut terdiri dari bahan hukum primer dan bahan hukum sekunder. ${ }^{5}$

a. Bahan hukumprimer

Bahan hukum primer yaitu bahan hukum dasar atau bahan asli yang diperoleh dari tangan pertama atau dari sumber asalnya yang pertama dan belum diuraikan orang lain. Bahan hukum primer ini dari membaca peraturan dasar, peraturan perundang-undangan, dan norma hukum.

b. Bahan hukumsekunder

Bahan hukum sekunder adalah bahan-bahan hukum yang erat kaitannya dengan bahan hukum primer dan dapat membantu menganalisis dan memahami bahan hukum primer.

\section{Pengumpulan Bahan Hukum}

Proses pengumpulan bahan hukum yang dipergunakan dalam penyusunan penelitian ini antara lain dengan melakukan langkah-langkah dalam penelitian hukum, yaitu kajian pustaka, identifikasi badan hukum, editing, analisis dan mengeliminasi hal-hal yang tidak relevan untuk menetapkan isu hukum yang akan dipecahkan.pengumpulan bahan-

${ }^{4}$ Ibid., hal. 137.

${ }^{5}$ Peter Mahmud Marzuki, Penelitian Hukum, Kencana Prenada Media Group, Jakarta,2010, hal.155. 
bahan hukum yang sekiranya dipandang memiliki relevansi terhadap isu hukum, melakukan telaah atas isu hukum yang diajukan berdasarkan bahan-bahan yang telah dikumpulkan, menarik kesimpulan dalam bentuk argumentasi yang menjawab isu hukum, memberikan preskripsi berdasarkan argumentasi yang telah dibangun dalam kesimpulan.

\section{Analisis Bahan Hukum}

Analisa bahan penelitian dalam penelitian ini menggunakan analisis normatif kualitatif, yaitu cara untuk memperoleh gambaran singkat suatu masalah yang tidak didasarkan atas angka-angka statistik melainkan didasarkan atas suatu peraturan perundang-undangan yang berlaku maupun teori dan asas hukumserta berkaitan dengan permasalahan yang dibahas. Selanjutnya ditarik kesimpulan dengan menggunakan metode deduktif yaitu menyimpulkan pembahasan dari hal-hal yang bersifat umum menuju ke hal-hal yang bersifat khusus.

\section{PEMBAHASAN}

\section{a. Konsep Pengawasan}

Oleh karena penyelenggara pemerintahan merupakan manusia yang secara kodrati tidak pernah terlepas dari kekurangan, baik itu yang bersifat alamiah maupun yang disengaja maka penting dalam penyelenggaran pemerintahan diadakan tindakan pengawasan. Baik itu oleh badan penyelenggara pemerintahan ataupun oleh rakyat secara langsung. Mengingat Negara Hukum Indonesia menganut bentuk pemerintahan demokrasi yang dimana dalam penyelenggaraan pemerintahan secara harfiah bergantung sungguh daripada apa yang dikehendaki oleh rakyat selaku pemilik kedaulatan dan penggunaan kedauatan tersebut berdasrkan ketentuan hukum yang berlaku.

Guna untuk memastikan bahwa tindakan penyelenggara pemerintahan itu merupakan representassi dari kehendak rakyat serta tidak bertentangan dengan peraturan perundng undangan yang berlaku maka tindakan tersebut harus diawasi.Tindakakan pengawasan tidak terkecuali pada tingkat pemerintahan tertentu.

Artinya tindakan pengawasan terhadap penyelenggara pemerintahan tersebut berlaku pada setiap tingkat pemerintahan, dalam hal ini termasuk pengawasan terhadap Peraturan Daerah di Kabupaten Bojonegoro yang dilakukan oleh Gubernur Jawa Timur selaku wakil pemerintah pusat yang diberi wewenang oleh UndangUndang untuk melakukan pengawasan terhadap proses pembuatan dan pelaksanaan Peraturan Daerah maupun dalam hal mengeluarkan keputusan yang berkaitan dengan penyelenggaran pemerintahan pada umumnya.

Pada dasarnya pengawasan dikenal dalam ilmu manajemen dan ilmu administrasi pemerintahan, pengawasan selalu digunakan untuk memastikan proses kerja sesuai dengan standar yang ditetapkan sehingga apa yang menjadi target bisa tercapai. Dalam ilmu Manajemen pengawasan merupakan bagian dari fungsi manajemen, dimana pengawasan merupakan bentuk pengontrolan dari atasan terhadap kinerja bawahannya. Dalam ilmu manajemen pengawasan ditempatkan sebagai tahap terakhir dari fungsi manajemen. 
Dari segi manajerial pengawasan mengandung makna sebagai pengamatan dan pengontrolan atas pelaksanaan seluruh kegiatan unit organisasi untuk menjamin agar seluruh pekerjaan yang sedang dikerjakan berjalan sesuai dengan rencana dan aturan yang telah ditetapkan.

Sementara itu, dalam Hukum Administrasi Negara pengawasan dimaknai sebagai proses kegiatan membandingkan apa yang dijalankan, dilaksanakan, atau yang diselenggarakan itu dengan apa yang dikehendaki, direncanakan, atau diperintahkan. Hasil pengawasan ini harus dapat menunjukan kecocokan dan ketidak cocokan serta menemukan penyebab ketidak cocokan yang muncul.

Dalam konteks membangun pemerintahan yang berciri good governance, pengawasan merupakan aspek penting untuk menjaga fungsi pemerintahan sebagaimana mestinya.Dalam konteks ini penerapan pengawasan menjadi sama pentingnya dengan penerapan good governance itu sendiri karena untuk tercapainya tata kelolah pemerintahan yang baik maka perlu pengawasan untuk memastikan apa yang dikerjakan sesuai dengan apa yang diharapkan dan tidak bertentangan dengan kepentingan umum maupun peraturan perundang undangan yang berlaku, serta sebagai bentuk adanya funsi cek and balance antara lembaga penyelenggara pemerintahan.

Istilah pengawasan dalam bahasa Inggris disebut controling yang diterjemahkan dalam istilah pengawasan dan pengendalian, sehingga istilah controling lebih luas artinya daripada pengawasan. 6 Sementara dalam bahasa Indonesia sendiri adalah pengawasan berasal dari kata "awas" sehingga pengawasan dimaknai dengan kegiatan mengawasi saja. Sarwoto memberikan definisi Pengawasan adalah kegiatan manajer yang mengusahakan agar pekerjaanpekerjaan terlaksana sesuai dengan rencana yang ditetapkan atau hasil yang dikehendaki. ${ }^{7}$

Sementara M. Manulang memberikan definisi bahwa pengawasan yakni suatu proses untuk menetapkan pekerjaan sesuai dengan rencana semula. 8 Sujamto mengatakan bahwa pengawasan adalah segala usaha atau kegiatan untuk mengetahui nilai kenyataan yang sebenarnya mengenai pelaksanaan tugas dan kegiatan, apakah apakah sesuai dengan semestinya atau tidak. ${ }^{9}$ Dan Mc. Ferland mendefinisikan pengwasan ialah suatu proses dimana pimpinan ingin mengetahui apakah hasil pelaksanaan pekerja yang dilakukan oleh bawahanya sesuaidengan rencana, perintah, tujuan atau kebijaksaanaan yang telah ditentukan. ${ }^{10}$

Selanjutnya menurut SP. Siagian memberikan definisi tentang pengawasan sebagai proses pengamatan daripada pelaksanaan

\footnotetext{
${ }^{6}$ Victor M. Situmarang dan Jusuf Juhir, Aspek Pengawasan Melekat Dalam Lingkup Aparatur Pemerintah, hlm.18.

7 Sarwoto, Dasar-dasar organisasi dan Manajement, Ghalia Indonesia, Jakarta, hlm. 93.

8 M. Manulang, Dasar-dasar Management, Ghalia Indonesia, Jakarta 1997, hlm. 136.

${ }^{9}$ Jum Angriani, Hukum Administrasi Negara. Graha Ilmu, Yogyakarta, 2012, hlm. 78.

10 Soewarno Handayaningrat, Pengantar Studi Ilmu Admnistrasi Negara,. Ghalia Indonesia, Bogor, 2004, hlm. 74.
} 
seluruh kegiatan organisasi untuk menjamin agar semua pekerjaan yang sedang dilaksanakan berjalan sesuai dengan rencana yang telah ditentukan. Menurut Suyanto beliau menberi defnisi pengawasan adalah segala usaha atau kegiatan untuk mengetahui dan meniai kenyataan yang sebenarnya mengenai pelaksanaan tugas atau kegiatn, apakah sesuai dengan semestinya atau tidak.Pengawasan dari segi hukum merupakan penilaian tentag syah atau tidaknya suatu perbuatan pemerintah yang menimbulkan akibat hukum. ${ }^{11}$

Sedangkan Makmur menyatakan bahwa pengawasan adalah suatu bentuk pola pikir dan pola tindakan untuk memberikan pemahaman dan kesadaran kepada seseorang atau beberapa orang yang diberikan tugas untuk dilaksanakan dengan menggunakan berbagai sumber daya yang tersedia secara baik dan benar, sehingga tidak terjadi kesalahan dan penyimpangan yang sesungguhnya dapat menciptakan kerugin oleh lembaga atau organisasi yang bersangkutan. ${ }^{12}$

Prayudi, sebagaimana dikutip oleh Ni'matul Huda menyatakan bahwa pengawasaan dapat bersifat: Politik, apabila yang menjadi sasran adalah efektifitas dan/atau legitimasi, Yuridis bila yang menjadi sasaran merupakan penegakan hukum, Ekonomi bila yang menjadi sasaran merupakan efektifitas dan Moril apabila yang menjadi sasaran merupakan moralitas. Pengawasan dilakukan agar memperoleh umpan

11 Diana Halim Koencoro, Hukum Administrasi Negara, Ghalia Indonesia, Bogor, 2004, hlm. 74.

12 Makmur, Efektivitas Kebijakan Pengawasan, Refika Aditama, Bandung, 2011, hlm. 176.

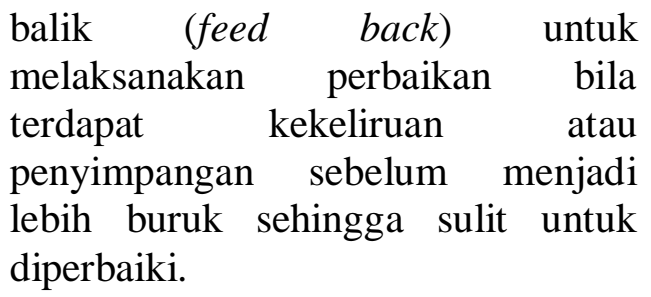

Pengawasan yang dimaksud memiliki fungsi untuk mengendalikan atau mengontrol sekaligus untuk mengevaluasi segala bentuk kebijakan-kebijakan yang telah ditetapkan.Berdasarkan uraian diatas maka penulis berpendapat bahwa pengawasan adalah serangkaian kegiatan yang dilakukan oleh atasan ataupun pihak lain yang berwenang guna menentukan apakah pelaksana kegiatan sesuai dengan fungsi dan kewenangan serta apakah kegiatan sesuai dengan apa yang menjadi tujuan yang telah ditetapkan.

Oleh sebab itu maka pengawasan perlu untuk dipandang sebagai suatu sistem informasi, karena kecepatan dan ketepatan tindakan korektif sebagai hasil pengawasan bergantung pada macam informasi yang diterima. Dengan demikian konsep pengawasan menunjukan adanya checks and balances untuk menghindari terjadinya kesewenang-wenangan lembaga Negara atau penyelenggara pemerintahan sehingga hak-hak umum dapat terjamin. Dari ketiga lembaga Negara atau penyelengara pemerintahan yang memiliki kekuasaan berbeda maka harus saling mengawasi agar tidak ada suatu lembaga yang memiliki kekuasaan yang lebih tinggi dari lembaga yang lainnya.

Partisipasi masyarakat (public participation) pada tatanan pemerintah yang demokrtis menghendaki adanya keterlibatan publik dalam proses pengmbilan keputusan (decision making process) 
yang semakin penting di era otonomi daerah.Dalam kurun waktu pelaksnaan otonomi daerah, pemerintah daerah ditengarai banyak melakukan penyimpangan dan kesalahan persepsi mengenai otonomi daerah.

Dengan adanya berbagi kasus pembatalan Perda oleh Pemerintah Pusat ini menandakan bahwa pengelolaan pemerintah daerah masih jauh dari harapan pemberian otonomi derah itu sendiri dan ini harus menjdi kenyataan yang mesti diterima oleh semua kalangan. Mengingat banyaknya kebijakan yang diambil oleh penyelenggara pemerintahan yang dapat merugikan Masyarakat maka setiap kebijakan yang diambil oleh pemerintah harus ada peran aktif dari Masyarakat untuk mengawasi sebagai bentuk penggunaan kedaulatan secara lansung sehingga kekeliruan yang berpotensi merugikan Masyarakat dalam pengambilan kebijakan oleh penyelenggara pemerintahan dapat diminimalisir.

\section{b. Pengawasan Peraturan Daerah Oleh Gubernur}

Di dalam penyelenggaraan Pemerintahan Daerah selain dikenal pengawasan preventif dan represif juga dikenal pengawasan umum. Pengawasan umum adalah pengawasan yang dilakukan secara langsung oleh pemerintah pusat melalui kementerian ataupun yang dlakukan melalui pemerintah daerah tingkat Provinsi terhadap penyelenggaraan pemerintahan tingkat Kabupaten/Kota yang kewenangan tersebut didelegasikan melalui Undang-Undang Nomor 23 Tahun 2014 tentang Pemerintahan Daerah, dalam rangka ikut mengawasi segala bentuk penyelenggaraan pemerintahan daerah termasuk dalam hal produk hukum daerah baik itu yang berupa Peraturan Daerah, Peraturan Kepala Daerah maupun Keputusan Kepala Daerah.

Pengawasan umum terkait dengan jalannya pemerintahan daerah sebelumnya telah termuat dalam Undang-Undang Nomor 5 Tahun 1976 yang diatur dalam Pasal 71, kemudian ditegaskan kembali dalam Undang-Undang Nomor 23 Tahun 2014 tentang Pemerintahan Daerah, sebagaimana telah diubah dengan Undang-Undang Nomor 9 Tahun 2015 Perubahan Kedua Atas Undang-Undaang Nomor 23 Tahun 2014 tentang Pemerintahan Daerah, serta Peraturan Pemerintah Nomor 12 Tahun 2017 Tentang Pembinaan dan Pengawasan Penyelenggaraan Pemerintahan Daerah.

Secara historis, landasan hukum diterapkanya pengawasan umum ini adalah amanat dari Keputusan Presiden Republik Indonesia No. 44 Tahun 1974 dimana dalam keputusan tersebut memuat tentang kewajiban setiap departemen untuk untuk menyelenggarakan fungsi pengawasan atas pelaksanaan tugas pokoknya sesuai dengan kebijaksanaan umum yang ditetapkan oleh Presiden dan berlandaskan peraturan perundangundangan yang berlaku. ${ }^{13}$

Tujuan pengawasan menurut Sujamto adalah mengetahui dan menilai kenyataan yang sebenarnya tentang pelaksanaan tugas dan pekerjaan apakah semestinya atau tidak. Sedangkan tujuan pengawasan menurut Victor Situmorang dan Jusuf Juhir adalah sebagai berikut:

${ }^{13}$ Irawan Soejito, Pengawasan Terhadap Peraturan Daerah dan Keputusan Kepala Daerah, hlm. 76. 
1. Menjamin ketetapan pelaksanaan sesuai dengan rencana, kebijaksanaan dan perintah;

2. Menertibkan koordinasi kegiatan-kegiaatan;

3. Mencegah pemborosan dan penyelewengan;

4. Menjmin terwujudnya kepuasan masyarakat atas barang dan jasa yang dihasilkan; dan

5. Membina kepercayaan terhadap kepemimpinan organisasi. ${ }^{14}$

Dari uraian tersebut dapat disimpulkan bahwa tujuan pengawasan adalah agar bagaimana pelaksanaan kegiatan dapat diketahui sedatail mungkin tentang hal-hal yang berkaitan dengan pelaksanaan kerja, hasil kerja, kendala-kendala yang dihadapi dalam pekerjaan, apakah pekerjaan sesuai dengan standar atau rencana yang ditetapkan, serta mengukur kesalahan yang terjadi sehingga dapat diperbaiki kearah yang lebih baik.

Namun pada intinya pengawasan itu bertujuan agar segala aktivitas penyelenggaraan pemerintahan oleh badan atau pejabat administrasi ketika mengeluarkan suatu keputusan atau kebijakan baik itu yang bersifat peraturan perundang-undangan ataupun tidak sebisa mungkin untuk selaras dengan apa yang menjadi Rancangan Pembangunan Jangka Panjang (RPJP) Nasional dan Rencana Pembangunan Jangka Menengah (RPJM) yang sudah ditetapkan, agar tidak bertentangan dengan peraturan perundang-

${ }^{14}$ Herman Yanti, Mekanisme Pengawasan Terhadap Peraturan Daerah Menurut Undang-Undang Nomor 32 Tahun 2004, hlm. 40 . undangan yang lebih tinggi, dan tidak bertentangan dengan kepentingan hukum serta dalam penyelenggaraan pemerintahan dapat terwujudnya pengelolaan pemerintahan yang baik atau yang sering disebut dengan istilah goodgovernance.

Selain dari pengawasan umum yang dilakukan secara langsung oleh pemerintah pusat melalui kementerian dalam rangka ikut mengawasi segala bentuk penyelenggaraan pemerintahan daerah termasuk dalam hal produk hukum daerah, juga terhadap penyelenggaraan pemerintahan daerah Kabupaten/Kota terdapat fungsi Gubernur sebagai wakil Pemerintah Pusat sebagaimana diatur dalam Pasal 91 ayat (1) UU No. 23 Tahun 2014 yang menentukan bahwa:

"Dalam melaksanakan
pembinaan dan pengawasan
terhadap penyelenggaraan
urusan pemerintahan yang
menjadi kewenangan Daerah
Kabupaten/Kota dan tugas
pembantuan oleh Daerah
Kabupaten/Kota, Presiden
dibantu oleh Gubernur sebagai
wakil Pemerintah Pusat".

Sedangkan pada ayat (2) ditentukan bahwa dalam melaksanakan pembinaan dan pengawasan sebagaimana dimaksud pada ayat (1) Gubernur sebagai wakil Pemerintah Pusat mempunyai tugas sebagai berikut:

1. Mengordinasikan pembinaan dan

pengawasanpenyelenggaraan tugas pembantuan di Daerah Kabupaten/Kota;

2. Melakukan monitiring, evaluasi, dan supervisi terhadap penyelenggaraan 
Pemerinthan Daerah

Kabupaten/Kota yang ada di wilayahnya;

3. Memberdayakan dan memfasilitasi Daerah

Kabupaten/Kota di wilayahnya;

4. Melakukan evaluasi terhadap rancangan Perda

Kabupaten/Kota tentang RPJPD, RPJMD, APBD, Perubahan APBD, tata ruang daerah, pajak daerah, dan retribusi daerah;

5. Melakukan pengawasan terhadap Perda Kabupten/Kota; dan

6. Melaksanakan tugas lain sesuai dengan ketentuan peraturan perundang undangan.

Selanjutnya pada ayat (3) ditentukan bahwa dalam melaksanakan tugas sebagaimana dimaksud ayat (2), Gubernur sebagai wakil Pemerintah Pusat mempunyai wewenang sebagai berikut:

1. Membatalkan Perda Kabupaten/Kota dan peraturan Bupati/Walikota;

2. Memberikan penghargaan atau sanksi kepada Bupati/Walikota terkait dengan penyelenggaraan Pemerintahan Daerah;

3. Menyelesaikan perselisihan dalam penyelenggaraan fungsi pemerintahan antar Daerah Kabupaten/Kota dalam 1 (satu) Daerah Provinsi;

4. Memberikan persetujuan terhadap rancangan Perda Kabupaten/Kota tentang pembentukan dan susunan Perangkat Daerah Kabupaten/Kota; dan
5. Melaksanakan wewenang lain sesuai dengan ketentuan peraturan perundang undangan.

Berdasarkan ketentuan tersebut di atas menunjukan bahwa Gubernur sebagai Wakil Pemerintaah Pusat yang berada di Daerah memiliki kewenangan yang begitu luas dalam hal melakukn pembinaan dan pengawasan terhadap penyelenggaraan Pemerintahan Daerah Kabupaten/Kota, selain dari itu tugas dan kewenangan tersebut dapat didelegasikan kepada Wakil Gubernur. Artinya bahwa untuk menjalankan fungsi pengawasan terhadap penyelenggaraan pemerintah daerah Kabupaten/Kota, Gubernur tidak terikat untuk melaksanakan sendiri namun oleh undang-undang diberikan kelonggaran sehingga fungsi tersebut dapat dijalankan oleh Wakil Gubernur.

Hal tersebut telah diatur lebih lanjut melalui Peraturan Pemerintah Nomor 12 Tahun 2017 tentang Pembinaan dan Pengawasan Penyelenggaraan Pemerintahan Daerah, khususnya pada Pasal 10 ayat (1) yang menentukan bahwa pengawasan penyelenggaraan pemerintahan daerah:

1. Provinsi, dilakukan oleh Menteri Dalam Negeri (Menteri) untuk pengawasan umum, dan Menteri teknis/Kepala Lembaga Pemerintah Non Kemeterian untuk pengawasan teknis; dan

2. Kabupaten/Kota,dilaksanakan oleh gubernur sebagai wakil pemerintah pusat untuk pengawasan umum dan teknis. 
Namun sebelum membahas lebih jauh tentang pengawasan, khususya mengenai pengawasan Peraturan Daerah Kabupaten/Kota oleh Gubernur, penulis sebaiknya akan mengemukakan terlebih dahulu tentang pemerintahan daerah itu sendiri. Berdasarkan pada ketentuan Pasal 1 angka 3 UU No. 23 Tahun 2014 tentang Pemerintahan Daerah telah ditentukan bahwa Pemerintah Daerah adalah Kepala Daerah yang memimpin pelaksanaan urusan pemerintahan yang menjadi kewenangan Daerah otonom. Sedangkan Daerah Otonomi adalah kesatuan masyarakat hukum yang mempunyai batas batas wilayah yang berwenang mengatur dan mengurus urusan pemerintahan dan kepentingan masyarakat setempat menurut prakarsa sendiri berdasarkan aspirasi masyarakat dalam sistem Negara Kesatuan Republik Indonesia.

Oleh karena itu dalam menjalankan urusan pemerintahan, Daerah berwenang menetapkan Kebijakan Daerah yang menjadi kewenangan

Daerah.Kebijakantersebut meliputi Peraturan Daerah (PERDA), Peraturan Kepala Daerah (PERKADA), dan Keputusan Kepala Daerah. Hal ini sebagaimana diatur dalam Pasal 17 ayat (1) UU No. 23 Tahun 2014 yang menentukan bahwa daerah berhak menetapkan kebijakan Daerah untuk menyelenggarakan urusan pemerintahan yang menjadi kewenangan daerah. Kemudian dalam penjelasan pasal tersebut ditentukan bahwa yang dimaksud dengan kebijakan Daerah adalah Perda, Perkada dan Keputusan Kepala Daerah.

Peraturan Daerah (PERDA) Kabupaten/Kota dibuat oleh
Bupati/Walikota bersama dengan Dewan Perwakilan Rakyat Daerah (DPRD) Kabupaten/Kota selaku penyelenggara pemeritahan di Daerah Kabupaten/Kota, termasuk dalam hal ini adalah Kabupaten Bojonegoro. PERDA yang dibuat oleh daerah Kabupaten Bojonegoro hanya berlaku dalam batas-batas yurisdiksi daerah yang bersangkutan. Daerah dalam pembentukan PERDA semata-mata dalam hal penyelenggaraan Otonomi Daerah dan Tugas Pembantuan. ${ }^{15}$

Penyelenggara Pemerintahan Daerah Kabupaten/Kota dalam menetapkan PERDA dan PERKADA, selain memperhatikan aspirasi masyarakat dan kekhasan daerah juga wajib untuk memperhatikan hal-hal yang ditentukan oleh peraturaan perundang-undangan yang berlaku.Karena PERDA maupun PERKADA tidak boleh bertentangn dengan peraturan perundangundangan yang lebih tinggi, asasasas umum pemerintahan yang baik (AUPB), dan Peraturan Daerah lainnya pada Daerah yang bersangkutan.

Disamping itu PERDA sebagai bagian dari sistem peraturan perundang-undangan tidak boleh bertentangan dengan kepentingan umum dan/atau kesusilaan. ${ }^{16}$ Maka untuk memastikan bahwa tidak ada pelanggaran hukum dalam pembentukan Peraturan Daerah, khususnya dalam hal ini PERDA Kabupaten/Kota adalah dengan

\footnotetext{
${ }^{15}$ Lihat pada ketentuan Pasal 236 ayat (1) Undang- Undang Republik Indonesia Nomor 23 Tahun 2014 Tentang Pemerintahan Daerah.
} 
adanya mekasime pengawasan atau kontrol.Pengawasan atau kontrol yang dimaksud dapat dilakukan sebagai upaya pencegahan maupun sebagai upaya dalam rangka menindaklanjuti.Atau juga disebut sebagai pengawasan preventif dan pengawasan represif.Berikut ini diuraikan mengenai pengawasan yang dimaksud tersebut.

\section{SIMPULAN}

Perandan fungsi pengawasan Gubernur terhadap Peraturan Daerah adalah untuk memastikan bahwa Peraturan Daerah yang dibuat tersebut tidak bertentangan dengan peraturan perundang-undangan yang ada di atasnya agar tidak terjadi tumpang tindih baik dari segi kewenangan maupun dari segi materi muatan, dan Gubernur sebagai wakildari pada Pemerintah Pusat yang ada di daerah diberi kewenangan untuk itu.

\section{SARAN}

Pengawasan terhadap Peraturan Daerah, khususnya Peraturan Daerah Kabupaten/Kota perlu ditingkatkan.Terutama pengawasan yang bersifat preventif, dimana pencegahan atas potensi timbulnya Peraturan Daerah bermasalah lebih penting dibandingkan dengan mekanisme pengujian sebagai upaya represif atas Peraturan Daerah yang bermasalah.

\section{DAFTAR PUSTAKA}

Diana Halim Koencoro, Hukum Administrasi Negara, Ghalia Indonesia, Bogor, 2004.

\begin{tabular}{|c|c|c|}
\hline Herman & Yanti, & Mekanisme \\
\hline
\end{tabular}

Undang-Undang Nomor 32 Tahun 2004.

Jimly Asshiddiqie, Hukum Tata Negara dan Pilar-Pilar Demokrasi, (Jakarta: Sinar Grafika), 2011.

Jum Angriani, Hukum Administrasi Negara. Graha Ilmu, Yogyakarta, 2012.

Makmur, Efektivitas Kebijakan Pengawasan, Refika Aditama, Bandung, 2011.

M. Manulang, Dasar-dasar Management, Ghalia Indonesia, Jakarta, 1997.

Peter Mahmud Marzuki, Penelitian Hukum, Cet. 5, Edisi Pertama, PT Interpratama Offset, Jakarta, 2009.

-------, Penelitian Hukum, Kencana Prenada Media Group, Jakarta,2010.

Soewarno Handayaningrat, Pengantar Studi Ilmu Admnistrasi Negara,. Ghalia Indonesia, Bogor, 2004.

Undang-Undang Republik Indonesia Nomor 23 Tahun 2014 Tentang Pemerintahan Daerah. 